\title{
Molecular characterization of an endolithic microbial community in dolomite rock in the central alps (Switzerland)
}

\author{
Horath, T ; Bachofen, R
}

\begin{abstract}
Endolithic microorganisms colonize the pores in exposed dolomite rocks in the Piora Valley in the Swiss Alps. They appear as distinct grayish-green bands about 1-8 $\mathrm{mm}$ below the rock surface. Based on environmental small subunit ribosomal RNA gene sequences, a diverse community driven by photosynthesis has been found. Cyanobacteria (57 clones), especially the genus Leptolyngbya, form the functional basis for an endolithic community which contains a wide spectrum of so far not characterized species of chemotrophic Bacteria (64 clones) with mainly Actinobacteria, Alpha-Proteobacteria, Bacteroidetes, and Acidobacteria, as well as a cluster within the Chloroflexaceae. Furthermore, a cluster within the Crenarchaeotes (40 clones) has been detected. Although the eukaryotic diversity was outside the scope of the study, an amoeba (39 clones), and several green algae (51 clones) have been observed. We conclude that the bacterial diversity in this endolithic habitat, especially of chemotrophic, nonpigmented organisms, is considerable and that Archaea are present as well.
\end{abstract}

DOI: https://doi.org/10.1007/s00248-008-9483-7

Posted at the Zurich Open Repository and Archive, University of Zurich

ZORA URL: https://doi.org/10.5167/uzh-18300

Journal Article

Published Version

Originally published at:

Horath, T; Bachofen, R (2009). Molecular characterization of an endolithic microbial community in dolomite rock in the central alps (Switzerland). Microbial Ecology, 58(2):290-306.

DOI: https://doi.org/10.1007/s00248-008-9483-7 


\title{
Molecular Characterization of an Endolithic Microbial Community in Dolomite Rock in the Central Alps (Switzerland)
}

\author{
Thomas Horath • Reinhard Bachofen
}

Received: 12 August 2008 / Accepted: 19 December 2008 / Published online: 28 January 2009

(C) Springer Science + Business Media, LLC 2009

\begin{abstract}
Endolithic microorganisms colonize the pores in exposed dolomite rocks in the Piora Valley in the Swiss Alps. They appear as distinct grayish-green bands about $1-8 \mathrm{~mm}$ below the rock surface. Based on environmental small subunit ribosomal RNA gene sequences, a diverse community driven by photosynthesis has been found. Cyanobacteria (57 clones), especially the genus Leptolyngbya, form the functional basis for an endolithic community which contains a wide spectrum of so far not characterized species of chemotrophic Bacteria (64 clones) with mainly Actinobacteria, Alpha-Proteobacteria, Bacteroidetes, and Acidobacteria, as well as a cluster within the Chloroflexaceae. Furthermore, a cluster within the Crenarchaeotes (40 clones) has been detected. Although the eukaryotic diversity was outside the scope of the study, an amoeba (39 clones), and several green algae (51 clones) have been observed. We conclude that the bacterial diversity in this endolithic habitat, especially of chemotrophic, nonpigmented organisms, is considerable and that Archaea are present as well.
\end{abstract}

\section{Introduction}

Microorganisms inhabiting rock were first observed and described 100 years ago [19, 45, 79], nevertheless, except for cyanobacteria, little is known about the community composition and the biodiversity of these microbial ecosystems. They are typical for hot and cold arid

\section{T. Horath $\cdot$ R. Bachofen $(\bowtie)$}

Institute of Plant Biology/Microbiology, University of Zürich,

Zollikerstr. 107,

CH-8008 Zürich, Switzerland

e-mail: bachofen@botinst.uzh.ch environments where in the pores of the rock, they are partially sheltered from a number of physical stresses such as solar radiation, heat, cold, or desiccation. Various organisms settle on the surface and invade pores and cracks. Within the rock, they form a structured biofilm, a clearly defined organismic layer or band a few millimeters below the surface [15-17, 24-26, 35, 42, 44, 58, 65, 88-90]. Contrary to submerged biofilms, endolithic biofilms are patchier due to local inhomogeneities of rock structures and environments [42]. These communities contain bacteria, fungi, and eukaryotic microalgae [81, 82]. They form complex physiological networks tied to solid particles by extracellular polymeric substances (EPS). The synthesis of these polymers is controlled by different environmental stress factors (e.g. [77]). The organismic composition is governed by the hostile environment. Water is only periodically available in the form of rain, dew, or just atmospheric humidity. Therefore, EPS are most important for the endolithic population as they retain water and act as osmoprotectant and nutrient reservoirs. In the Alps, main nutrients are scarce, and the daily and seasonal temperatures oscillate widely. At high altitudes, the sunlight with a strong part in the UV is a further life threatening factor [95]. Habitats with such fluctuating environmental conditions pose a strong challenge to organisms, and life there may reach its limits at least in certain periods.

Endolithic microorganisms have gained interest in the past decades for several reasons: e.g., as possible analogs of extraterrestrial life, such as life on Mars [2, 24, 40, 43, 46, $59,63,73,94,95]$, for the study of the mechanisms of adaptation to extreme and hostile conditions [30, 36, 87, 96], to study the processes of weathering and mineral dissolution $[12,91]$ or for phylogenetic reasons [17, 29, 65, 86, 88, 89].

Endolithic microbial communities are found worldwide in dry and aquatic environments. The ones studied and 
described came from cliffs of the Niagara escarpment $[32,56,57]$ from streams in the UK [68] and from gypsum cliffs in Nova Scotia [28]. They are found in hot and arid desert environments [5-7, 23], in travertine in Turkey [69], in arctic and antarctic locations [2, 26, 27, 44, 74, 93], in mountainous regions $[42,65,88,89]$, and in the marine littorals [92]. Most investigations have been based on traditional techniques, mainly light and electron microscopy, and on cultures. They have usually been focused on pigmented microorganisms, oxygenic phototrophs such as green algae and cyanobacteria as well as filaments of fungi as partners of lichen symbiosis. Cyanobacteria are important in the early stages of primary succession processes in soils, especially because many species are able to fix dinitrogen [47]. However, it must be assumed that a variety of heterotrophic organisms will rapidly follow the phototrophs after their invasion. So far, molecular methods have hardly been used. They have even been thought to be useless in studying endoliths [93]. However, molecular techniques are now successfully applied to characterize endolithic communities such as the cyanobacterial population in the dolomite rocks in Switzerland [82], the endolithic community in the McMurdo Dry Valleys in the Antarctica [17], or the microbial population in rocks of the Rocky Mountains [29, 65, 89].

The objective of the present study is to describe the broad genetic diversity of the endolithic bacterial populations present in the dolomite formations of the Swiss Alps by culture independent molecular methods. Dolomite rocks $\left(\mathrm{CaMg}\left(\mathrm{CO}_{3}\right)_{2}\right)$ in the Piora Valley in southern Switzerland are often bare of vegetation and exposed to hostile conditions. Such weathered rocks harbor chasmoendolithic and cryptoendolithic (definitions, see [34]) phototrophic and heterotrophic microbial communities which become easily visible as grayish-green bands some millimeters below the surface. This hidden microbial ecosystem was first characterized by Diels [19] in the Italian Dolomites and has been studied in Piora dolomite by molecular [82], spectroscopical, and optical techniques [42]. At a depth of 2 to $8 \mathrm{~mm}$, the phototrophic microorganisms still receive enough photosynthetic active radiation while they are protected from excessive sunlight with a high fraction in the UV range [42]. As most organisms of environmental samples cannot be cultured by standard methods yet, a description of the microbial diversity of this special microbial ecosystem has been obtained by sequence analyses of polymerase chain reaction (PCR) amplified fragments of the small subunit of the ribosomal ribonucleic acid gene (SSU rRNA gene). The knowledge of the composition of the microbial community will help to better understand the biogeochemical processes that occur in these habitats. Preliminary results have been presented earlier $[41,81]$.

\section{Materials and Methods}

\section{Sampling Site}

Dolomite rock material was collected in the Piora Valley in the southern part of the Swiss Alps at an elevation of $1,965 \mathrm{~m}$ above sea level in summer 2001 and 2003. The coordinates of the specific sampling site are 46 $32^{\prime} 51^{\prime \prime} \mathrm{N}, 8^{\circ} 43^{\prime} 05^{\prime \prime} \mathrm{E}$. Details of the site are given by Sigler et al. [82] and Horath et al. [42]. The geology of the Piora Valley, oriented eastwest, is characterized by a dolomite trough, a few hundred meters wide, surrounded by crystalline rock formations. Due to erosion by wind and water, the dolomite is often exposed to the atmosphere, forming white cliffs. Such sites are sparsely covered with black epilithic cyanobacteria and lichens. Especially in slightly weathered dolomite, endolithic microorganisms are easily observed when the surface layer is removed. They form a grayish-green layer about 1-8 mm below the rock surface. Rock pieces of some millimeters or centimeters in size were cut off from the surface with an ethanol-flamed chisel and hammer, and samples with visible endolithic bands were kept in Falcon tubes in the dark at $4^{\circ} \mathrm{C}$ until DNA extraction in the laboratory.

\section{DNA Extraction}

DNA extraction was performed as described by Sigler et al. [82]. In brief, 0.5 to $0.6 \mathrm{~g}$ of rock samples of the green layer was scratched into a sterile empty Petri dish with sterilized tools, then put into 2-ml sterile microfuge tubes containing $1.0 \mathrm{ml}$ of extraction buffer $(50 \mathrm{mM} \mathrm{NaCl}, 50 \mathrm{mM}$ ethylene diamine tetra acetic acid disodium salt dihydrate (EDTA; Fluka 03685), 50 mM 2-amino-2-hydroxymethyl-propane1,3-diol hydrochloride (TRIS-HCl; Fluka 93363) and 5\% sodium dodecyl sulfate (SDS; Fluka 71729), final $\mathrm{pH} 8$ ), $0.5 \mathrm{~g}$ glass beads ( 0.1 and $0.5 \mathrm{~mm}$ in diameter) and eventually $0.5 \mathrm{ml}$ of a phenol-chloroform-isoamylalcoholmixture $(v / v / v=49.5 / 49.5 / 1$, Fluka 77618). The tubes were sealed with Parafilm ${ }^{\circledR}$, shaken in a bead beater ("FastPrep ${ }^{\circledR}$ ", BIO 101, La Jolla, CA, USA) at $5.5 \mathrm{~m} \mathrm{~s}^{-1}$ for $30 \mathrm{~s}$ and centrifuged for $4 \mathrm{~min}$ at $10,000 \times g$. Nucleic acids were isolated by standard phenol/chloroform extraction and ethanol precipitation [75]. The dry DNA pellet was redissolved in $50 \mu \mathrm{l}$ distilled autoclaved water.

\section{PCR Amplification of SSU rRNA Genes}

The small subunit rRNA gene was amplified from genomic DNA by PCR with several pairs of primers (see Table 1). PCR was performed in 200- $\mu$ l thin-walled tubes on a "Progene" or a "Genius" thermocycler respectively (Techne LTD, Duxford Cambridge, U.K) in a volume of $25 \mu \mathrm{l}$. The reaction mixture contained (final concentrations): the 


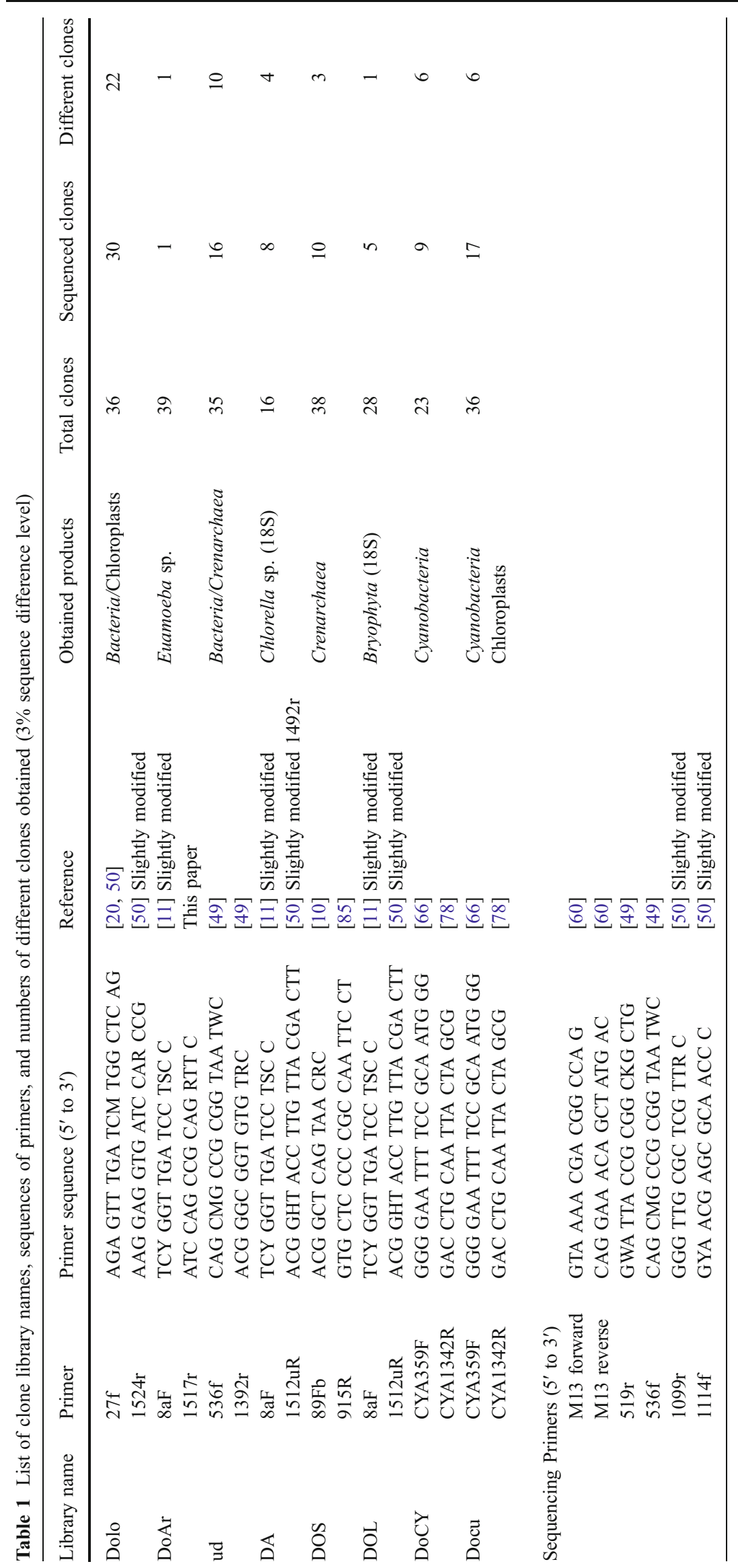


appropriate Taq buffer $(1 \times), 1.5-2.0 \mathrm{mM} \mathrm{MgCl}_{2}, 0.1 \mathrm{mg} \mathrm{ml}^{-1}$ bovine serum albumine, $0.2 \mathrm{mM}$ dNTP's, $200 \mathrm{nM}$ forward primer, $200 \mathrm{nM}$ reverse primer, 40-100 $\mathrm{U} \mathrm{ml}^{-1} \mathrm{Taq}$ Polymerase (Sigma, Promega, Invitrogen, or Pharmacia), and approximately 50-100 ng template DNA. PCR was run under the following conditions: initial denaturation at $94^{\circ} \mathrm{C}$ for $2 \mathrm{~min}$, 10 cycles of $94^{\circ} \mathrm{C}$ for $20 \mathrm{~s}, 60-0.5^{\circ} \mathrm{C} /$ cycle for $30 \mathrm{~s}, 72^{\circ} \mathrm{C}$ for 60 to $90 \mathrm{~s}$ depending on the length of the product, 20 cycles of $94^{\circ} \mathrm{C}$ for $20 \mathrm{~s}, 50^{\circ} \mathrm{C}$ to $58^{\circ} \mathrm{C}$ for $30 \mathrm{~s}$, depending on the annealing temperature of the primers, $72^{\circ} \mathrm{C}$ for 60 to $90 \mathrm{~s}$. The products were checked on a $1 \%$ agarose gel in $0.5 \times$ TAE buffer [1 $\times 40 \mathrm{mM}$ Tris base (2-amino-2-hydroxymethyl-propane-1,3diol), $20 \mathrm{mM}$ glacial acetic acid, $1 \mathrm{mM} \mathrm{Na}{ }_{2}$ EDTA of $\left.\mathrm{pH} 8.0\right]$.

\section{Cloning}

PCR-amplified products were cloned without purification with the TOPO TA cloning kit (Invitrogen) as specified by the manufacturer's manual.

\section{Restriction Fragment Length Polymorphism}

After plasmid DNA mini preparation with alkaline lysis [75] and the reamplification of the SSU rRNA gene with M13 primers, restriction was carried out with Hinf I and Hae III and the fragments analyzed on a Spreadex ${ }^{\circledR}$ EL 800 Wide Mini S-50 gel (Elchrom Scientific) run at $55^{\circ} \mathrm{C}$ for $1 \mathrm{~h}$ at $10 \mathrm{~V} \mathrm{~cm}^{-1}$. The gels were stained with 10,000 times diluted $1 \%(w / v)$ ethidium bromide and viewed with $302 \mathrm{~nm} \mathrm{UV}$ illumination.

\section{DNA Sequencing}

Reamplified plasmid inserts were purified by filtration (Amicon Microcon YM-100 filter, Millipore Corporation, Bedford, MA, USA), and 100 to $180 \mathrm{ng}$ DNA (dissolved in $1 \mu \mathrm{H} \mathrm{H}_{2} \mathrm{O}$ ) were used for sequencing-PCR using $0.8 \mu$ l BigDye ${ }^{\circledR}$ Terminator v3.1 (Applied Biosystems), $1.5 \mu \mathrm{l}$ sequencing buffer $(5 \times)$, $6.8 \mu \mathrm{l}$ of $\mathrm{H}_{2} \mathrm{O}$ Milli $\mathrm{Q}$, and $0.25 \mu \mathrm{l}(5 \mu \mathrm{M})$ of one of the sequencing primers listed in Table 1. Before the automated loading into the polymers on the 48-capillary sequencer (Applied Biosystems 3730 DNA Analyzer), the PCR products were purified by centrifugation through Sephadex G50 (Amersham Pharmacia). The raw sequences were aligned and combined using the Gene Codes Sequencher software (www.genecodes.com).

\section{Nucleotide Sequence Accession Numbers}

The SSU rRNA gene sequences found have been deposited at the DNA Data Bank of Japan and can be retrieved under the accession numbers AB257629 to AB257698 and AB334273 to AB334298.
Phylogenetic Tools

Rarefaction curves were generated with the program "Analytic Rarefaction 1.3" provided by Steven M. Holland at "http://www.uga.edu/ strata/software/Software.html". The newly obtained SSU rRNA gene sequences were compared with known sequences in the NCBI database (Genbank) at the National Center for Biotechnology Information (http://www.ncbi.nlm.nih.gov/) by the use of the Basic Local Alignment Search Tool (BLAST) [1] to determine their approximate phylogenetic affiliation.

The EMBOSS Pairwise Alignment Tool at "http://www.ebi. ac.uk/emboss/align/" provided by the European Bioinformatics Institute was used to compare single sequences in the following mode: "Method: water"; "Gap Open: 10.0"; "Gap Extend: 10.0"; "Molecule: DNA"; "Matrix: DNAfull".

The new SSU rRNA gene sequences were further added to the rRNA gene sequence database of the Technical University of Munich (ssu_jan04_corr_opt.arb, release February 2005) by the use of the program package ARB ([54], http://www.arb-home.de). The integrated tool ARB_ALIGN was used for automatic sequence alignment, which was then checked with a critical eye according to the secondary structure of the rRNA molecule, and corrected. If missing, the latest best fitting sequences found by NCBIBLAST were added to the ARB database.

The final phylogenetic trees were derived from the basic phylogenetic tree of about 51,000 SSU rRNA sequences after adding the new sequences with appropriate filters, and the "Maximum Parsimony Method." Bootstrap values were calculated from the sequences used in the final trees by using the "Phylip Parsimony Method", integrated in ARB, compressing vertical gaps, running 100 bootstrap samples.

In order to plot a phylogenetic tree, many different algorithms are available today, which all lead to acceptable results if they are based on a proper sequence alignment [52]. Therefore, emphasis has been put on an accurate alignment. The trees presented are copies of the largest tree, namely "tree_1000_jan05" in the ARB database "ssu_jan04_corr_opt.arb". After adding the new sequences to the existing tree containing more than 50,000 single SSU rRNA sequences, the new trees have been reduced to a convenient size for illustration. Bootstrap values have been calculated although they are not considered to be very important, since these values can be shifted by omitting closely branching sequences before calculation (Eichenberger, Ch., personal communication).

Bootstrapping has been introduced to provide confidence intervals in phylogenetic calculations [13, 21], because calculated trees are never fully true and require flexible interpretations. When using Maximum Parsimony, Distance Matrix (Neighbor Joining), or Maximum Likelihood, the result should not be overestimated because its variation 
among different methods is a negligible indicator of the confidence interval [21]. Furthermore, the order of adding sequences to a calculation has an effect on the tree topology [e.g., 53]. Thus removing and readding complete groups to a tree may rearrange its branching. In our case, it improved the congruence of the results of ARB and NCBI.

\section{Results}

In a previous study, we investigated endolithic bacterial communities in exposed weathered dolomite rocks by confocal laser scanning microscopy, pigment analysis, and reflectance spectroscopy [42]. Communities depending on photosynthesis usually harbor a sum of heterotrophic organisms which feed on exudates and lysed cells. As it is hardly possible to characterize the diversity of environmental microorganisms by cultivating them, we analyzed the endolithic heterotrophic community by cloning and sequencing their SSU rRNA genes.

\section{SSU rRNA Gene Clone Libraries}

Isolation of DNA from fine powdered rock material posed some difficulties as DNA tended to stick to and precipitate with the inorganic rock debris. Suitable amounts of DNA were obtained following the procedure of Sigler et al. [82]. To evaluate the diversity of the prokaryotic endolithic community, eight independent clone libraries with different combinations of universal and phylogenetic group-specific oligonucleotide primers were constructed, including two libraries with specific cyanobacterial primers (Table 1). In total, 254 clones were analyzed by restriction fragment length polymorphism (RFLP), 96 of which were sequenced. Assuming a threshold of a minimal 3\% sequence difference between species [84], 53 sequences fell into distinctly related groups. From these 53 phylotypes, 45 belong to Bacteria (including three chloroplasts of two green algae and a moss), three to Archaea, and five to Eukarya (Table 2). Scanning the graphic alignment of the NCBIBLAST analysis of the new sequences, no chimeras have been detected ([1], http://www.ncbi.nlm.nih.gov/).

A wide diversity was found in the clone libraries obtained with the bacterial primer pair $27 \mathrm{f} / 1524 \mathrm{r}$ and the "universal" primer pair 536f/1392r. In the bacterial library, 22 out of 36 , and in the "universal" library, nine out of 35 clones were different. The other primer pairs resulted in less diverse libraries. As an extreme, primer pairs $8 \mathrm{aF} / 1517 \mathrm{r}$ (DoAr) and $8 \mathrm{aF} / 1512 \mathrm{uR}$ (DOL) yielded 39 and 28 RFLP-identical clones, respectively (Table 2). Primer $1517 \mathrm{r}$ (Table 1) was originally designed to increase the number of Archaea clones but resulted in the detection of a so far unknown 18S rRNA gene sequence fragment closely related to Saccamoeba limax (99.4\%, clone DoAr09).

Rarefaction curves for all the eight clone libraries are shown in Fig. 1. The shapes of the curves "Dolo" and "ud" indicate that further sampling would increase the number of operational taxonomic units (OTUs, 3\% difference level). In contrast, the other graphs, except for the summarized data, level off rapidly, a phenomenon for discussion.

A quarter of the obtained bacterial sequences (64 out of a total of 251 clones) originated from phototrophic oxygenic organisms. Cyanobacteria were numerous with 11 phylotypes, chloroplasts of green algae (Dolo-01, Dolo-34) or of bryophytes (Docu-30) with three different phylotypes (seven clones). Among the heterotrophic species, the representatives of the phylum Actinobacteria were the most numerous (15 clones, seven phylotypes), followed by Alpha Proteobacteria (14 clones, ten phylotypes), and Bacteroidetes (12 clones, two phylotypes). Acidobacteria (seven clones, two phylotypes), Gamma Proteobacteria (five clones, one phylotype), and Gemmatimonadetes (two clones, two phylotypes) were less frequent. Only one clone was found in each of the proposed divisions TM6 and TM7, as well as in the phylum Planctomycetes (Fig. 2 and Table 2). The green nonsulfur phototrophic bacteria group of the Chloroflexi yielded six clones (four phylotypes). The sum of bacterial phyla found in the dolomite of the Piora Valley covers ten of approximately 75 bacterial phyla known or postulated so far $[51,72,76]$. All the archaeal sequences found fell into the group of uncultured Crenarchaeotes (Table 2). Eukaryotic 18S rRNA gene sequences have been found in groups related to Euamoebida, Bryophyta, and Chlorophyta ( 83 out of a total of 251 clones, five phylotypes; Table 2). The phylogenetic trees give an overview of the distribution of the newly detected SSU rRNA gene sequences in the domains of Bacteria, Archaea, and Eukarya (Figs. 3a, b, 4, and 5).

Within all sequences analyzed, the percentages of sequence identity with SSU rRNA gene sequences available at GenBank (http://www.ncbi.nlm.nih.gov/) range between $85.2 \%$ and $99.7 \%$. Clone "DOS_02", on a length of $791 \mathrm{bp}$, was even $99.9 \%$ identical with the uncultured archaeon clone HL17 (AJ608203) in loam from a bank of the river Waal in the Netherlands, while clone "Dolo-07", on a length of $1,425 \mathrm{bp}$, shows only an $83.8 \%$ similarity with the uncultured Chloroflexus clone pItb-vmat-61 (AB294962) from a microbial mat in a shallow submarine hot spring in Japan (Table 2). For some sequences, ARB or "EMBOSS Pairwise Alignment Algorithms" have found different closest relatives as compared to NCBI-BLAST, but then often with smaller sequence coverage. Among the 45 different bacterial phylotypes, $18(40 \%)$ were less than $95 \%$ identical to the closest $16 \mathrm{~S}$ rRNA gene in the nucleotide sequence database, 14 phylotypes $(31 \%)$ were 
Table 2 Phylogenetic affinities of SSU rRNA gene sequences obtained from dolomite in the Piora Valley, Central Alps

\begin{tabular}{|c|c|c|c|c|c|}
\hline Clone & Frequency $^{\mathrm{a}}$ & $\begin{array}{l}\text { Phylogenetic } \\
\text { affiliation }\end{array}$ & Closest NCBI-BLAST Match (accession no.) & $\begin{array}{l}\% \\
\text { Identity }\end{array}$ & $\begin{array}{l}\text { Accession } \\
\text { no. }\end{array}$ \\
\hline Dolo-26 & $1 / 36$ & Acidobacteria & Uncultured bacterium clone Amb_16S_1159 (EF018708) & 96.8 & AB257649 \\
\hline ud01 & $6 / 35$ & Acidobacteria & Uncultured bacterium clone Elev_16S_1031 (EF019528) & 98.8 & $\mathrm{AB} 257683$ \\
\hline ud02 & $6 / 35$ & Actinobacteria & Bacterium Ellin504 (AY960767) & 96.4 & AB257684 \\
\hline Dolo-16 & $1 / 36$ & Actinobacteria & $\begin{array}{l}\text { Goodfellowia coeruleoviolacea, strain NRRL B-24058 } \\
\text { (DQ093349) }\end{array}$ & 94.1 & AB257641 \\
\hline Dolo-39 & $1 / 36$ & Actinobacteria & Micrococcineae strain Ellin124 (AF408966) & 93.9 & AB257657 \\
\hline ud31 & $3 / 35$ & Actinobacteria & Uncultured actinobacterium clone FBP460 (AY250884) & 99.1 & AB257697 \\
\hline Dolo-10 & $1 / 36$ & Actinobacteria & Uncultured bacterium AT425_EubY10 (AY053479) & 91.8 & AB257636 \\
\hline ud17 & $2 / 35$ & Actinobacteria & Uncultured bacterium clone C-F-15 (AF443586) & 94.6 & $\mathrm{AB} 257690$ \\
\hline ud19 & $1 / 35$ & Actinobacteria & Uncultured organism clone DLE037 (EF127609) & 92.7 & AB257692 \\
\hline Dolo-28 & $2 / 36$ & Alpha proteobacteria & Brevundimonas variabilis (AJ227783) & 98.8 & $\mathrm{AB} 257650$ \\
\hline Dolo-09 & $1 / 36$ & Alpha proteobacteria & Marine alpha proteobacterium strain V4.MO.17 (AJ508754) & 94.9 & $\mathrm{AB} 257635$ \\
\hline Dolo-08 & $1 / 36$ & Alpha proteobacteria & Sphingomonas asaccharolytica, strain IFO 15499-T (Y09639) & 96.7 & AB257634 \\
\hline Dolo-14 & $1 / 36$ & Alpha proteobacteria & Sphingomonas asaccharolytica, strain IFO 15499-T (Y09639) & 97.4 & AB257639 \\
\hline Dolo-04 & $1 / 36$ & Alpha proteobacteria & Uncultured alpha proteobacterium clone OS-C38 (EF612400) & 95.6 & AB257630 \\
\hline Dolo-11 & $1 / 36$ & Alpha proteobacteria & Uncultured bacterium clone "Hot Creek 25" (AY168723) & 91.7 & AB257637 \\
\hline Dolo-24 & $1 / 36$ & Alpha proteobacteria & Uncultured bacterium clone JSC8-E1 (DQ532238) & 97.9 & AB257648 \\
\hline Dolo-22 & $3 / 36$ & Alpha proteobacteria & Uncultured proteobacterium 59H11 (AF245037) & 98.5 & AB257646 \\
\hline Dolo-05 & $2 / 36$ & Alpha proteobacteria & Uncultured soil bacterium clone PK_XIII (EF540444) & 97.0 & $\mathrm{AB} 257631$ \\
\hline Dolo-32 & $1 / 36$ & Alpha proteobacteria & Uncultured soil bacterium clone PK_XIII (EF540444) & 93.0 & $\mathrm{AB} 257653$ \\
\hline ud04 & $7 / 35$ & Bacteroidetes & Uncultured Bacteroidetes bacterium clone J35E6 (DQ365993) & 96.5 & $\mathrm{AB} 257685$ \\
\hline ud10 & $5 / 35$ & Bacteroidetes & Uncultured soil bacterium clone M52_Pitesti (DQ378268) & 98.2 & AB257688 \\
\hline Dolo-06 & $5 / 36$ & $\begin{array}{l}\text { Gamma } \\
\text { proteobacteria }\end{array}$ & Xanthomonas-like sp. V4.BO.41 (AJ244722) & 97.3 & $\mathrm{AB} 257632$ \\
\hline Dolo-19 & $1 / 36$ & Gemmatimonadetes & Uncultured bacterium clone 5-31 (DQ833469) & 90.4 & AB257644 \\
\hline Dolo-18 & $1 / 36$ & Gemmatimonadetes & Uncultured Gemmatimonadetes clone Skagen138 (DQ640715) & 93.4 & AB257643 \\
\hline Dolo-21 & $1 / 36$ & Planctomycetes & Planctomyces sp. (strain: Schlesner 658) (X81954) & 96.7 & $\mathrm{AB} 257645$ \\
\hline Dolo-31 & $1 / 36$ & TM6 & Uncultured bacterium clone Ebpr8 (AF255643) & 93.5 & $\mathrm{AB} 257652$ \\
\hline ud08 & $1 / 35$ & TM7 & $\begin{array}{l}\text { Uncultured candidate division TM7 bacterium clone } 71 \\
\text { (AF513102) }\end{array}$ & 92.1 & AB257687 \\
\hline DoCY-44 & $4 / 23$ & Cyanobacteria & Gloeobacter violaceus PCC 7421 (BA000045) / (AP006573) & 95.7 & AB334275 \\
\hline Docu-04 & $3 / 36$ & Cyanobacteria & Leptolyngbya frigida ANT.LH52.2 (AY493575) & 95.0 & AB334284 \\
\hline Docu-01 & $22 / 36$ & Cyanobacteria & Leptolyngbya sp. CENA 112 (EF088337) & 96.9 & AB334282 \\
\hline Docu-19 & $4 / 36$ & Cyanobacteria & Leptolyngbya sp. CNP1-B3-C9 (AY239600) & 94.2 & AB334292 \\
\hline Docu-28 & $3 / 36$ & Cyanobacteria & Leptolyngbya sp. Greenland_7 (DQ431002) & 95.1 & AB334294 \\
\hline DoCY-46 & $4 / 23$ & Cyanobacteria & Nostoc sp. 'Pannaria aff. leproloma cyanobiont' (EF174228) & 98.9 & AB334277 \\
\hline DoCY-45 & $1 / 23$ & Cyanobacteria & Uncultured cyanobacterium clone 100M1_F2 (DQ514011) & 93.2 & AB334276 \\
\hline DoCY-55 & $1 / 23$ & Cyanobacteria & Uncultured cyanobacterium clone 100M1_F2 (DQ514011) & 96.7 & AB334280 \\
\hline DoCY-42 & $8 / 23$ & Cyanobacteria & Uncultured cyanobacterium clone HAVOmat106 (EF032780) & 94.0 & AB334274 \\
\hline Docu-24 & $2 / 36$ & Cyanobacteria & Uncultured cyanobacterium clone HAVOmat31 (EF032786) & 94.1 & AB334293 \\
\hline DoCY-39 & $5 / 23$ & Cyanobacteria & Uncultured Gloeobacter sp. clone HAVOmat17 (EF032784) & 95.8 & AB334273 \\
\hline Dolo-23 & $1 / 36$ & uncultured Chloroflexi & $\begin{array}{l}\text { Uncultured Chloroflexi bacterium clone AKYH1480 } \\
\text { (AY922118) }\end{array}$ & 96.0 & $\mathrm{AB} 257647$ \\
\hline ud07 & $2 / 35$ & uncultured Chloroflexi & $\begin{array}{l}\text { Uncultured Chloroflexi bacterium clone AKYH1521 } \\
\text { (AY922125) }\end{array}$ & 99.7 & AB257686 \\
\hline Dolo-07 & $2 / 36$ & uncultured Chloroflexi & Uncultured Chloroflexus clone pltb-vmat-61 (AB294962) & 83.8 & $\mathrm{AB} 257633$ \\
\hline Dolo-17 & $1 / 36$ & uncultured Chloroflexi & Uncultured Chloroflexus clone pltb-vmat-61 (AB294962) & 85.2 & AB257642 \\
\hline DOS_21 & $7 / 38$ & Crenarchaeota & Uncultured archaeon clone DRV-A006 (AY923076) & 98.2 & $\mathrm{AB} 257680$ \\
\hline DOS_02 & $21 / 38$ & Crenarchaeota & Uncultured archaeon clone HL17 (AJ608203) & 99.9 & AB257674 \\
\hline DOS_05 & $10 / 38$ & Crenarchaeota & Uncultured archaeon clone JFJ-WS-Arch07 (AJ867731) & 99.6 & AB257676 \\
\hline ud14 & $2 / 35$ & Crenarchaeota & unidentified archaeon SCA1150 (U62812) & 99.4 & AB257689 \\
\hline DOL_01 & $28 / 28$ & Bryophyta & Blindia acuta (AF023681) & 99.7 & AB257668 \\
\hline DA-01 & $7 / 16$ & Chlorophyta & Pseudomuriella sp. Itas 9/21 14-1d (AY195974) & 92.3 & AB257659 \\
\hline DA-04 & $6 / 16$ & Chlorophyta & Stichococcus bacillaris K4-4 (AB055866) & 98.6 & $\mathrm{AB} 257661$ \\
\hline DA-12 & $3 / 16$ & Chlorophyta & Uncultured Dunaliellaceae clone Amb_18S_930 & 94.6 & $\mathrm{AB} 257663$ \\
\hline
\end{tabular}


Table 2 (continued)

\begin{tabular}{|c|c|c|c|c|c|}
\hline Clone & Frequency $^{a}$ & $\begin{array}{l}\text { Phylogenetic } \\
\text { affiliation }\end{array}$ & Closest NCBI-BLAST Match (accession no.) & $\begin{array}{l}\% \\
\text { Identity }\end{array}$ & $\begin{array}{l}\text { Accession } \\
\text { no. }\end{array}$ \\
\hline & & & $(\mathrm{EF} 023670)$ & & \\
\hline Docu-30 & $2 / 36$ & Chloroplast & Chloroplast of Hymenostylium recurvirostre (DQ629553) & 99.7 & AB334295 \\
\hline Dolo-34 & $1 / 36$ & Chloroplast & Uncultured chlorophyte clone FQSS008 (EF522228) & 96.9 & AB257654 \\
\hline Dolo-01 & $4 / 36$ & Chloroplast & Uncultured chlorophyte clone FQSS008 (EF522228) & 97.5 & AB257629 \\
\hline DoAr-09 & $39 / 39$ & Euamoebida & Saccamoeba limax (AF293903) & 99.5 & AB257667 \\
\hline
\end{tabular}

${ }^{a}$ The frequency of the clones is given as the number of clones of one sort of phylotype divided by the total number of clones in that library

in the range between $95 \%$ and $97 \%$ sequence identity, showing genus level relation [84], while 13 phylotypes (29\%) were within the species level (more than 97\% sequence identity).

\section{Bacterial Community}

The quantitative distribution of the different mostly heterotrophic phylotypes in the bacterial clone libraries "ud" and "Dolo" (excluding chloroplasts and the specific cyanobacterial libraries "Docu" and "DoCY") is diagrammed in Fig. 2. There are four predominant groups accounting for more than $80 \%$ of 64 clones: the Actinobacteria together with Proteobacteria (alpha and gamma), Bacteroidetes, and Acidobacteria are the most numerous. Looking separately at individual bacterial phylotypes, the five clones ud01, ud02, ud04, ud10, and Dolo-06 are the most numerous ones, all in all accounting for $45 \%$ of the nonoxigenic "ud" and "Dolo" clones. Based on NCBI-BLAST [1], these phylotypes represent Bacteroidetes (ud04=10.9\%,
Figure 1 Rarefaction curves for the different libraries and for the sum of all clones obtained. The threshold is set at $3 \%$ sequence difference to distinguish between different OTUs. For clone names see, Table 1
Sum of all eight libraries
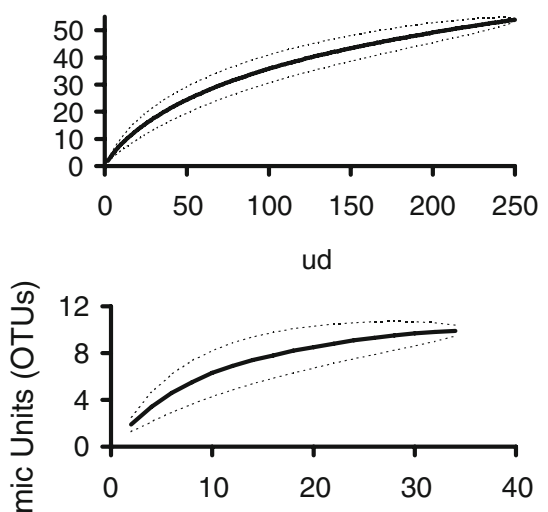

DOS

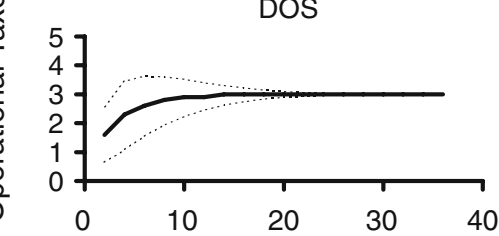

DoCY

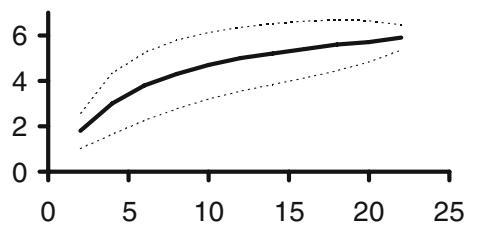

Dolo
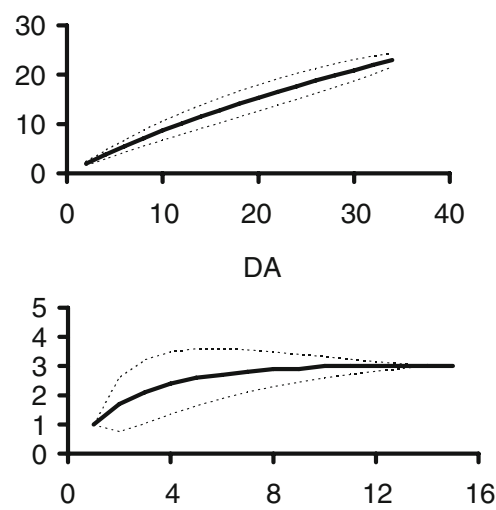

DoAr or DOL

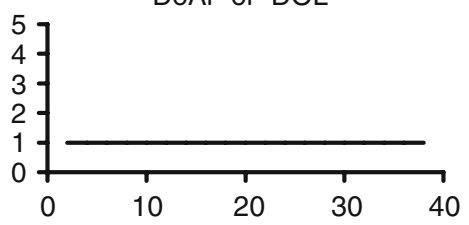

Docu

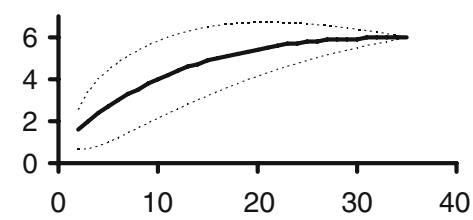

number of clones 
Figure 2 Distribution of phyla among the bacterial libraries "Dolo" and "ud". The five groups Actinobacteria, Proteobacteria (mainly Alphaproteobacteria), Bacteroidetes, Acidobacteria, and Chloroflexi are predominant in terms of the number of OTUs with $3 \%$ level distinction

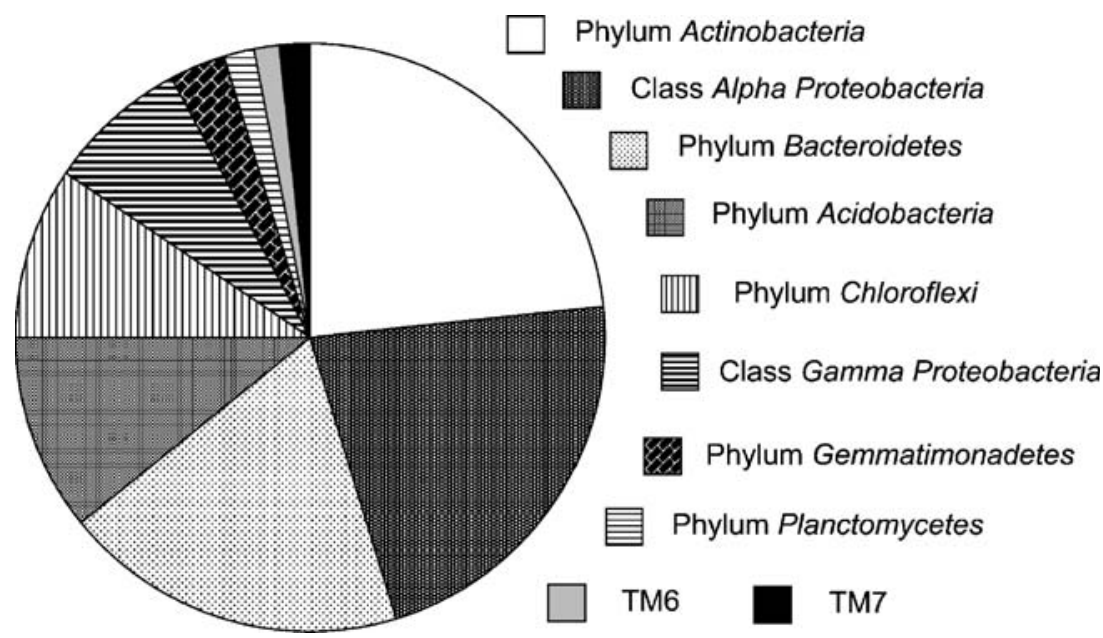

ud $10=7.8 \%$, each percentage referring to the sum of nonoxigenic "ud" and "Dolo" clones), Acidobacteria (ud01= 9.4\%), Actinobacteria (ud02=9.4\%), and Gamma Proteobacteria (Dolo-06 $=7.8 \%$; Table 2, and Fig. 2). None of these five most numerous sequences show a similarity to known SSU rRNA gene sequences of less than 95\%. Several bacterial groups collectively account for a significant fraction of the total number of clones, while individual phylotypes are not particularly numerous. Nine phylotypes belong to the class Alpha Proteobacteria representing 22\% of bacterial clones. Seven phylotypes belong to the phylum Actinobacteria and represent 23\% of bacterial clones. Four phylotypes affiliate with uncultured Chloroflexi, accounting for $9.4 \%$ of the clones. Two phylotypes fall into the category of the phylum Gemmatimonadetes and consist of one clone each (3.1\%). Phylotypes of Planctomycetes, of TM6 and of TM7 appear only once, each representing $1.6 \%$ of the bacterial clones. The phylogenetic position of the bacterial phylotypes is depicted in the trees in Fig. 3a and b.

\section{Archaea}

The archaeal library generated with the primer pairs $519 \mathrm{f} / 1392 \mathrm{r}$ and $89 \mathrm{Fb} / 915 \mathrm{R}$ (Table 1) resulted in three phylotypes - or four if ud14 and DOS_02 are counted as two separate phylotypes. They are $99.8 \%$ identical within their 420 bp fragment between positions 519 and 934 (Escherichia coli numbering). All the archaeal phylotypes found belong to the phylum Crenarchaeota and therein to the uncultured Crenarchaeota (Fig. 4). The phylotype of the clone DOS_02 amounts for the largest part of the crenarchaeal clones with 21 of 40 representatives $(52.5 \%)$. It is followed by DOS_05 with ten clones (25\%), DOS_ 21 with seven (17.5\%), and ud14 with two (5\%) out of 40 clones. All these clones show similarities of more than $98 \%$ with SSU rRNA gene sequences from the public database, but for the time being, these are all uncultured archaeons. The closest named organism is Cenarchaeum symbiosum, an uncultured marine sponge symbiote [37], with similarities of $86 \%$ to ud14 and $81 \%$ to DOS 02, according to the EMBOSS Pairwise Alignment Tool provided by the EBI.

\section{Eukaryotic Microorganisms}

The primer combinations $8 \mathrm{aF} / 1512 \mathrm{uR}$ and $8 \mathrm{aF} / 1517 \mathrm{r}$ resulted in several eukaryotic sequences of SSU rRNA (Table 2). As the clones DA-04 and DA-15 are quite similar (97.2\%), they are counted as one phylotype, likewise the clones DA-01 and DA-11, with 98.1\% similarity. Hence, there are five different phylotypes, three of which belong to the class Chlorophyta: one to the order Euamoebida in the class Lobosea, and one to a moss in the division of the Bryophyta (Fig. 5). The phylotype of DoAr09 is $99.4 \%$ identical to Saccamoeba limax and the most numerous, with 39 out of a total of 83 eukaryotic clones $(47 \%)$. Nevertheless, these numbers should not be overestimated, since they come from three combined clone libraries which were obtained under different conditions (chloroplasts not included). The moss represented by DOL_01 forms one third $(33.7 \%)$ of the eukaryotic clones and is followed by the clones DA-01 (8.4\%), DA-04 (7.2\%), and DA-12 (3.6\%), all belonging to the Chlorophyta. Two phylotypes, DA-01 and DA-12, have similarities of less than $95 \%$ to other sequences in public databases. DOL_01, DA-04, and DoAr-09 have NCBI-BLAST matches of more than $98 \%$. Interestingly, DOL_01 (AB257668) is 99.2\% identical to the Hymenostylium recurvirostre 18S rRNA (DQ629394), and Docu-30 (AB334295) is 99.7\% identical to the $H$. recurvirostre chloroplast 16S rRNA (DQ629553), which suggests that protonemata of Hymenostylium prosper in the interstices of dolomite rock. 


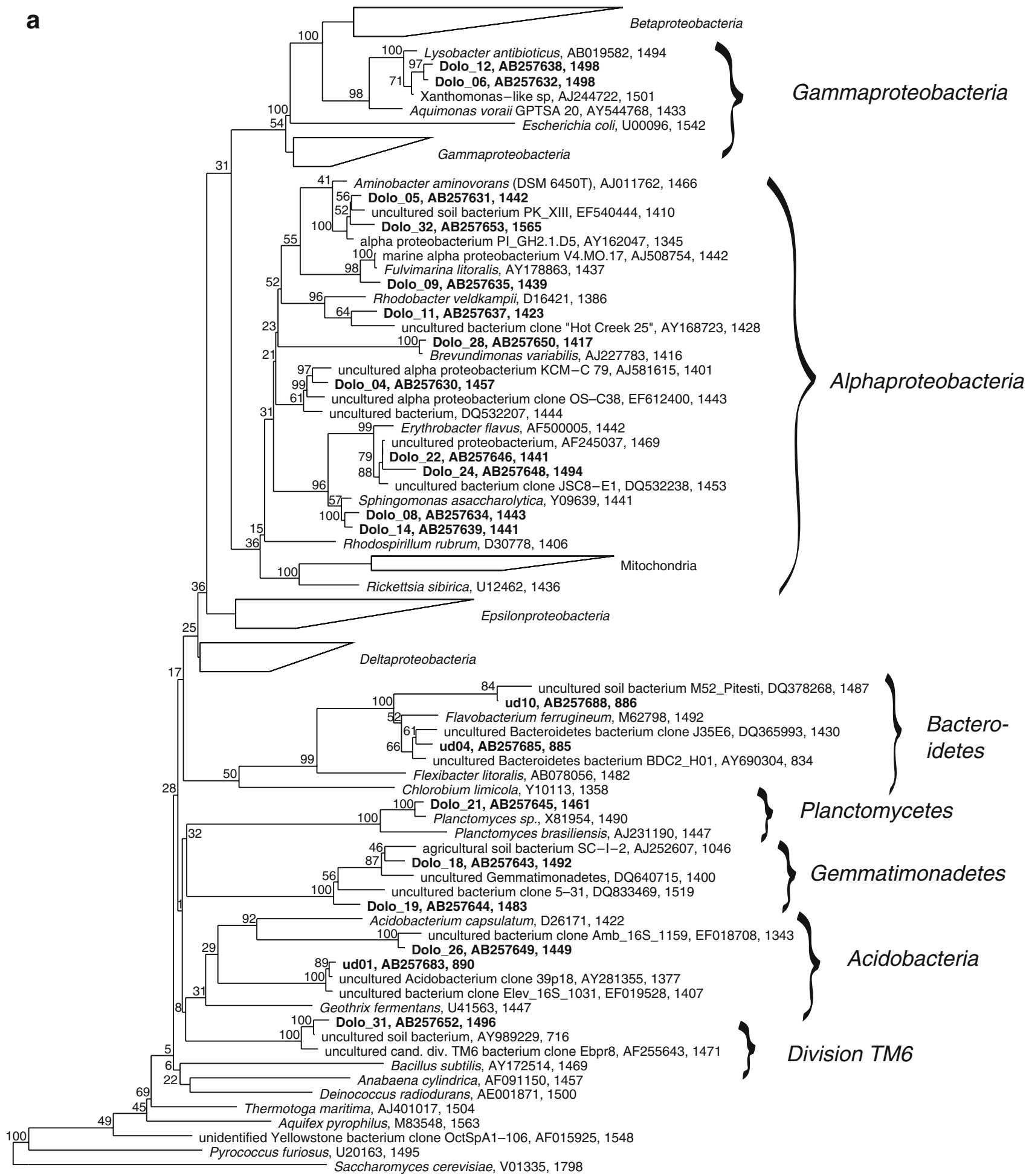

Figure 3 Phylogenetic tree with bacterial endolithic SSU rRNA gene sequences from alpine dolomite rock of the Piora Valley (in bold type) together with the closest relatives according to NCBI and ARB (tree calculated with ARB, Maximum Parsimony Method). The figures of
Bootstrap values are given in percent. Saccharomyces cerevisiae is used to root the tree. Accession numbers and the length of the sequences (nucleotides) are indicated after the names. a part $1, \mathbf{b}$ part 2 


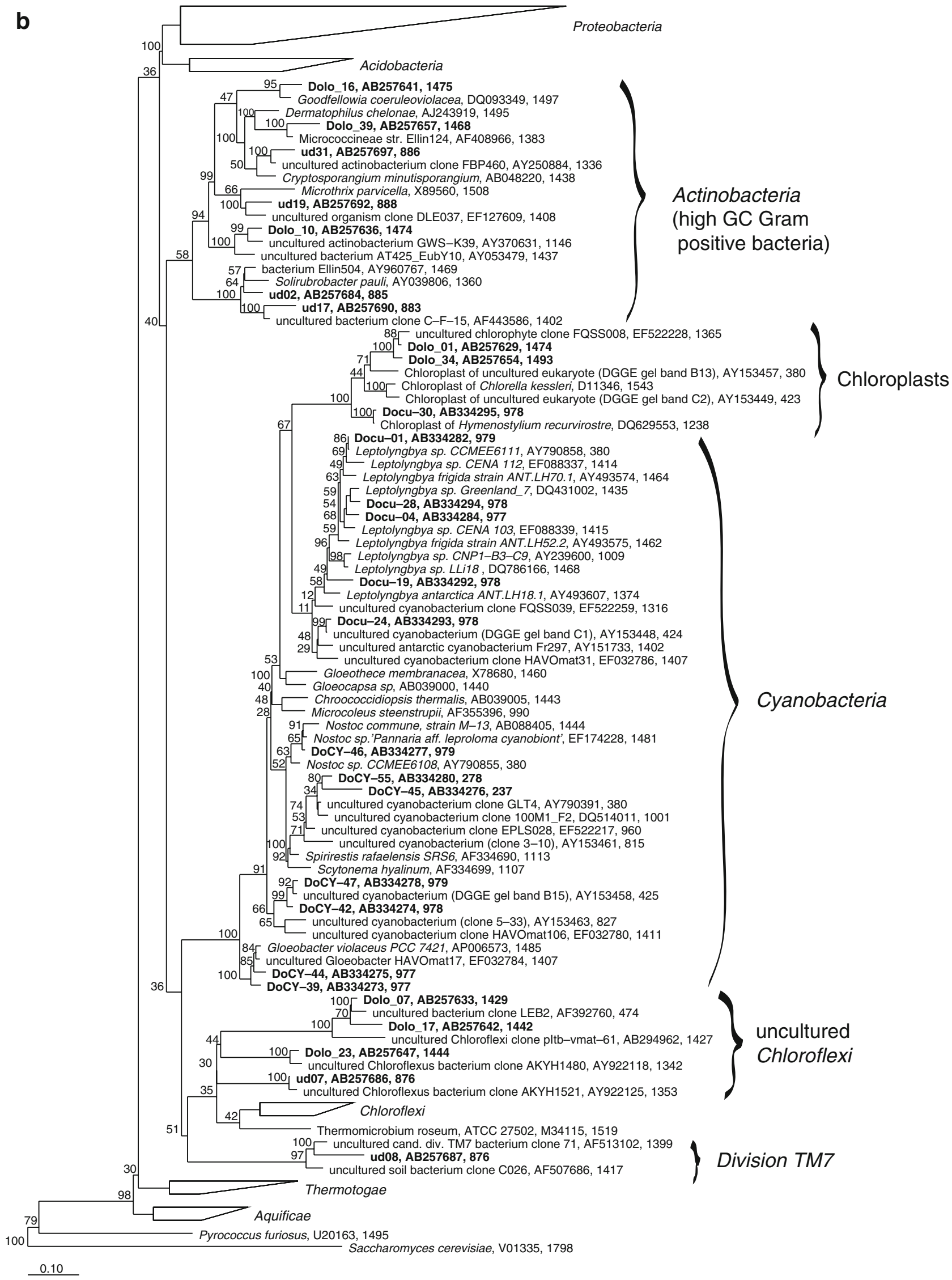

Figure 3 (continued) 
Figure 4 Phylogenetic tree of archaeal endolithic SSU rRNA gene sequences obtained from alpine dolomite rock of the Piora Valley (in bold type) together with other sequences of Archaea (tree calculated with ARB, Maximum Parsimony Method). All sequences found fall into the group of uncultured Crenarchaeota. E. coli and $S$. cerevisiae are used as the outgroup. The figures of Bootstrap values are given in percent. Accession numbers and the length of the sequences (nucleotides) are indicated after the names

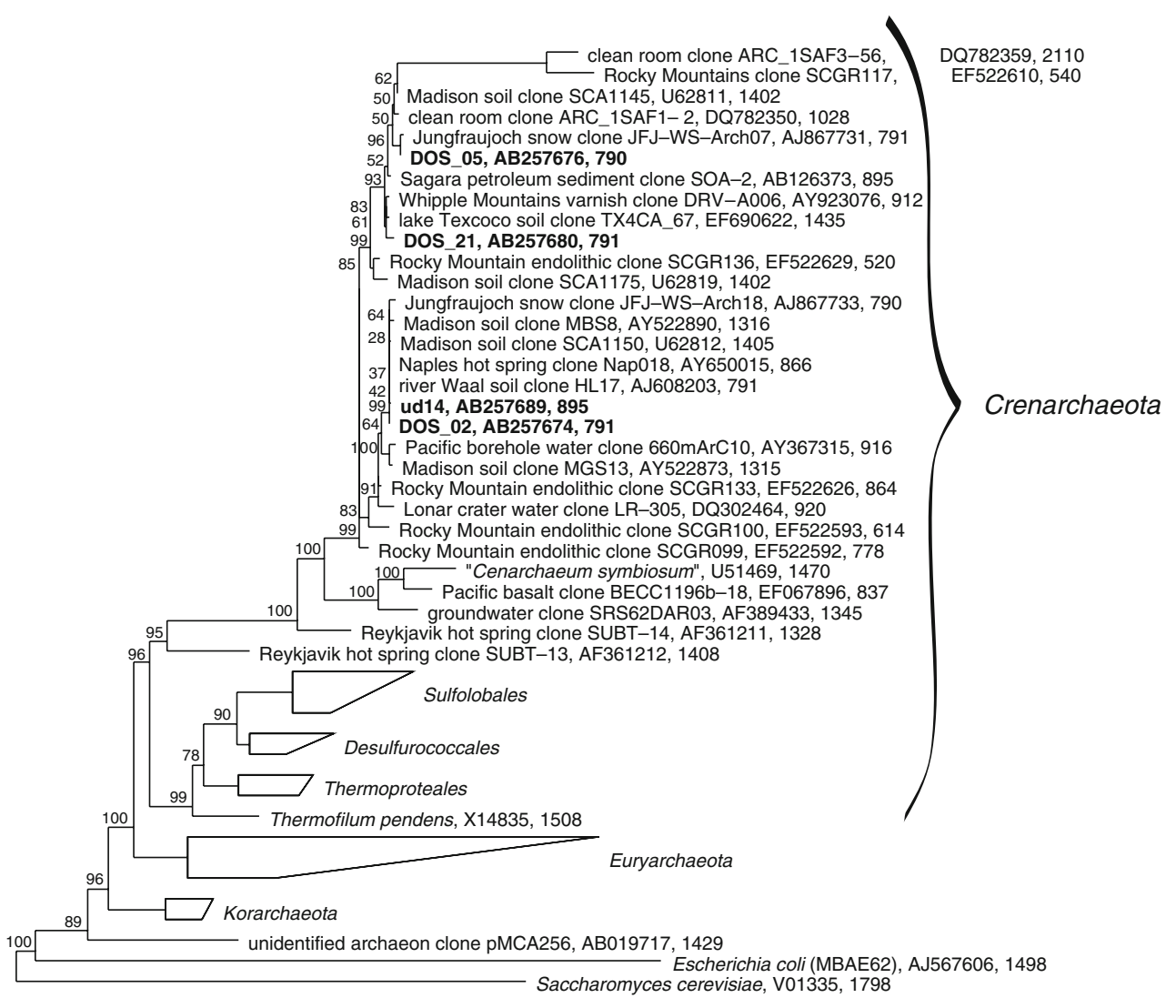

0.10
Cyanobacterial Libraries

Two libraries were constructed with the specific primers CYA359F/CYA1342R. One came from a direct extraction of DNA from dolomite rock (DoCY) as described before, the other was obtained from an enrichment in a ten times diluted cyanobacterial BG11 medium seeded with rock material containing an endolithic band (Docu). 16S rRNA gene amplification, cloning, and sequencing yielded five different Leptolyngbya species (Docu-01, Docu-04, Docu19, Docu-24, Docu-28) as well as a chloroplast of the moss $H$. recurvirostre (Docu-30, 99.7\%). The DoCY cloning yielded six different phylotypes related to Nostoc (DoCY46), Gloeobacter (DoCY-39 and DoCY-44), uncultured Spirirestis (DoCY-45 and DoCY-55), and an uncultured cyanobacterium (DoCY-42). The cyanobacterial sequences are included in the phylogenetic tree depicted in Fig. $3 \mathrm{~b}$.

\section{Discussion}

Many endolithic ecosystems were studied in the past century, focusing mainly on algal and cyanobacterial diversity, by use of culture techniques and microscopic morphotypes for identification [96]. As the various stress factors present in endolithic sites may induce variations in size, color, and morphology, one cannot rely on morphological properties in situ or after cultivation. Gloeocapsa sanguinea/alpina changes its color from red ( $G$. sanguinea) to blue ( $G$. alpina), depending on the environmental $\mathrm{pH}$ level [45]. Morphological information alone may substantially mislead taxonomic identification [65]. Neither can pure culture techniques cover the full biodiversity, since in such a community culture, replication times of different species vary considerably, and mutualistic relations between species may get lost. Furthermore, it is questionable whether the better known epilithic microorganisms differ from the endolithic ones, which are thought to be restricted to the subsurface only. As it has, so far, hardly been possible to culture most environmental microorganisms, culture-independent molecular methods are suitable to obtain more information on the bacterial diversity. Walker and Pace suggest that, compared to other terrestrial ecosystems such as soil, endolithic communities in the Rocky Mountains, the Antarctica or the ones described here, are relatively simple systems with a rather restricted diversity. However, they also admit that molecular surveys do not completely sample the genetic diversity of a community [90].

Diels [19] and Jaag [45] found cyanobacteria in European Dolomite sites, Bell [7] in semi-arid regions and 


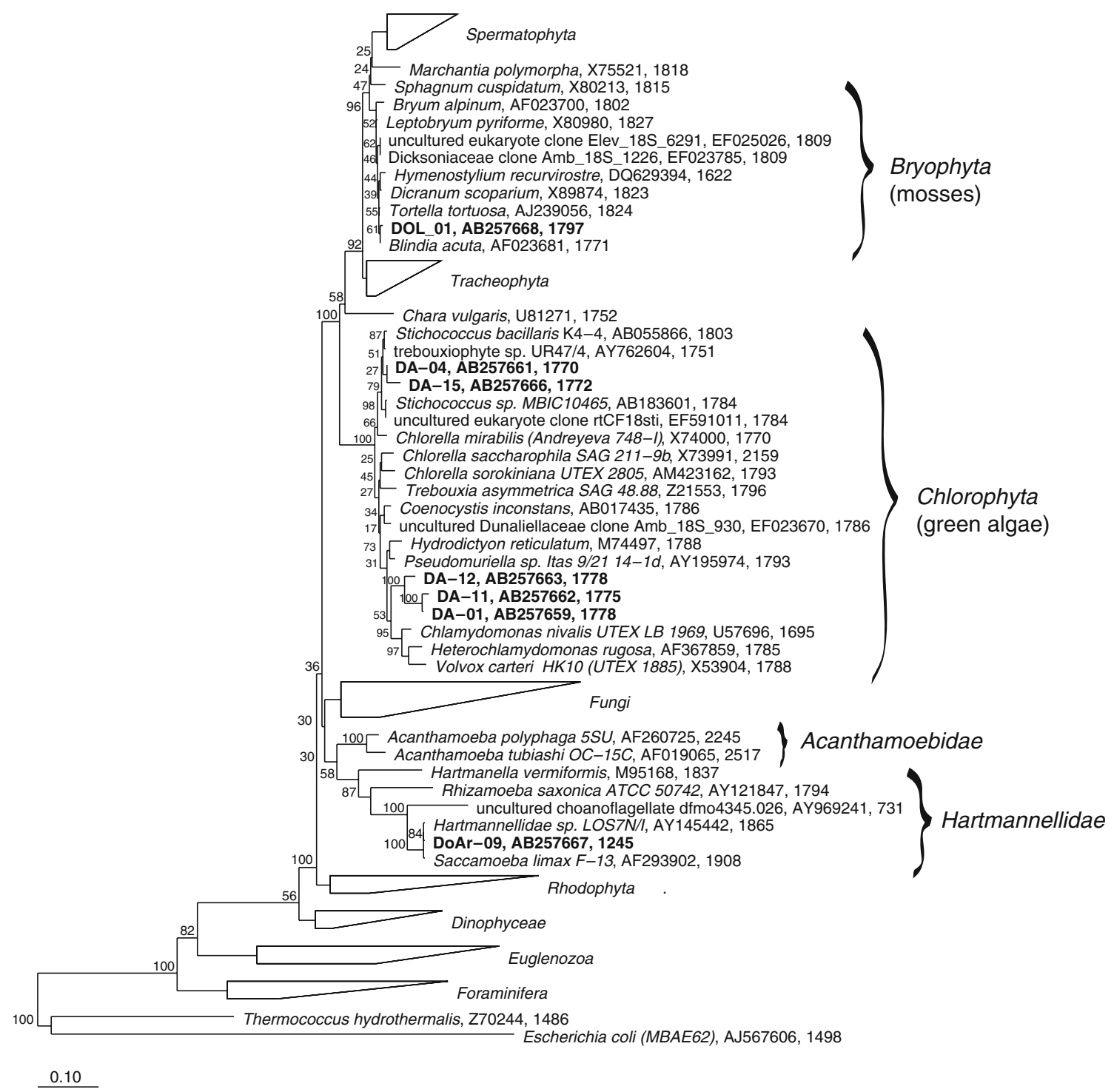

Figure 5 Phylogenetic tree of eukaryotic endolithic SSU rRNA gene sequences obtained from alpine dolomite rock of the Piora Valley (in bold type) together with other sequences of Eukarya (tree calculated with

deserts in the southwest of the United States, Nienow and Friedmann [64] in the Antarctica, and Ferris and Lowson [22] as well as Gerrath et al. [31, 32] in limestone of the Niagara escarpment, all of which were classified by microscopy and culture techniques. Only a few of those genera have been confirmed with molecular methods. In endolithic habitats, cyanobacterial species related to Plectonema [17] and Acaryochloris [18] have been found as well as species related to Anabaena, Chroococcidiopsis, Microcoleus, Nostoc, and Scytonema [82]. The relationship between most of these sequences and the cultured strains is less than 96\%. Up to now, Walker and Pace [89] have only found phylotypes "considerably different" from cultivated cyanobacteria. They have discovered two novel clades of specific endolithic cyanobacteria which are related to
ARB, Maximum Parsimony Method). Accession numbers and the length of the sequences are indicated after the names. E. coli is used to root the tree. The figures of Bootstrap values are given in percent

cultivated strains with less than about $94 \%$ sequence similarity \{Owl Canyon Sandstone clone OCSS038 (EF522486) as compared with Spirirestis rafaelensis (AF334690)\}. Lists of cultivated species and those of sequenced SSU rRNA genes hardly ever overlap, suggesting that species easy to cultivate may be the rare ones in nature. Norris and Castenholz [65] isolated endolithic phototrophs from rock material by culture techniques. Their list contains Gloeocapsa, very common in dolomite rock, as well as Schizothrix, Nostoc, and Leptolyngbya; all these genera were already mentioned by Jaag [45] or found with molecular methods by Sigler et al. [82]. However, about one third of the cultures listed by Norris and Castenholz have a similarity of less than $97 \%$ to the closest relatives known, and according to currently used criteria [84] may be 
considered to be new species. This indicates that the bacterial diversity in most ecosystems must be larger than what has so far been detected by microscopy or cultivation as well as by sequencing.

By using specific cyanobacterial primers (CYA359F and CYA1342R), we found 11 phylotypes of cyanobacteria and three different sequences of chloroplasts of two green algae and one moss (Table 2). The cyanobacterial sequences indicated as closest cultivated relatives Gloeobacter violaceus, Spirirestis rafaelensis, several Leptolyngbya sp., Nostoc edaphicum, and Nostoc commune. Microcoleus steenstrupii was found to be related to the clones DoCY-45 and DoCY55 , which were difficult to sequence and are only available as short sequences of about $200 \mathrm{bp}$. Sequences from the same sampling site, obtained earlier, suggest that $M$. steenstrupii as well as relatives of Nostoc PCC7120, of several Chroococcidiopsis sp., and of Chlorella sp. are also present there [82]. Sigler's DGGE band $\mathrm{C} 1$ obtained from an enrichment culture (AY153448) is now seen as the closest relative of our clone Docu-24. Both of them represent so far uncultivated cyanobacteria with $99.8 \%$ similarity between each other. The closest known cultivated strain to "band C1" is Leptolyngbya sp. PCC 9221 (94\%), which confirms that there is still a gap in our knowledge as far as cultivated strains and collected environmental sequences are concerned. Sigler's sequence of band 15 (AY153458) now shows the closest similarity to clone DoCY-47 (AB334278) while bands 3 and 14 come closest to clone 46C-WNS (AB374402), which was gathered from a very similar environment in the Grisons, Switzerland. Interestingly, we also found a single chloroplast sequence, Docu-30 (AB334295), which corresponds $99.7 \%$ with a known chloroplast sequence of the moss Hymenostylium recurvirostre (DQ629553). This is affirmed by the presence of the $18 \mathrm{~S}$ rRNA gene sequence of clone DOL_01 (AB257668) which is similar to the 18S rRNA gene sequence of Blindia acuta (AF023681) and of H. recurvirostre (DQ629394) by $99.5 \%$ and $99.2 \%$, respectively.

Most environmental information on endolithic microorganisms is available on cyanobacteria. Clusters of Leptolyngbya are widely present in broad variations in all investigated ecosystems, in endolithic communities in the Rocky Mountains, in travertine of the Yellowstone National Park, in deep-sea basalt, and in alpine Piora dolomite [55, $65,82,89$, and this paper]. Nostoc type filamentous organisms have been found in Piora and the Yellowstone, while relatives of coccoid Gloeobacter were observed in Piora and the Antarctica. Gloeocapsa, Synechococcus, Synechocystis, and Chroococcidiopsis are also present in all the above-mentioned systems but have not been detected in this study.

Little is known about the biodiversity of the heterotrophic bacterial communities accompanying the phototrophs. They were not dealt with in older studies for technical reasons. Sigler et al. [82] mentioned a large number of "non-cyanobacterial" clones without giving details. The phylogenetic tree (Fig. 3a and b) shows that in spite of the hostile environment, the heterotrophic endolithic population is quite diverse and consists of many different species. The cloning yielded 31 different chemotrophic bacterial clones with only a few doublets. This and the rarefaction curves of the clone libraries "Dolo" and "ud" indicate that the inventory of new sequences is far from complete (Fig. 1). It contrasts with the organismic composition found in antarctic endolithic communities, where in communities with cyanobacteria as primary producers only two heterotrophic groups, the $\alpha$ proteobacteria and the Thermus-Deinococcus group, were predominant besides the Cyanobacteria. The three groups together contributed to over $80 \%$ of the communities [17]. It remains to be tested whether it is possible to find more phylotypes in the McMurdo Dry Valleys or in the Piora dolomite by using different DNA extraction methods and different primers for the SSU rRNA gene. Using primer $1524 \mathrm{r}$, for instance, instead of primer $1525 \mathrm{r}$, with a difference of one base at the 3-prime end, already results in a strongly decreased number of detected cyanobacteria.

Most Piora sequences did not closely match with known sequences, and none of them were fully identical with a known sequence. The phylogenetic composition of the endolithic communities in Swiss dolomite was broader than the one in the Rocky mountains [89] with many phylotypes in the group of Actinobacteria, of Alphaproteobacteria, of Bacteriodetes, and of Acidobacteria. The group of Actinobacteria make up $23 \%$ of all phylotypes found in Piora dolomite, with a similar occurrence in the Rocky Mountains [89], on a wall in Fairy Cave, Glenwood Springs, CO, USA [3], and in rock varnish of the Whipple Mountains [48], but with $44 \%$, they are more frequent in limestone of Ek Balam, Yucatan, Mexico [62] and with 65\% predominant in rocks of the geothermal environment of the Yellowstone Park [88]. An explanation for the high fraction of Actinobacteria could be their strong cell wall and the capability of forming spores. Their high GC-content is also an advantage in extreme environments. In the dolomite of Central Switzerland, the overall sequence similarity of nonphototrophic prokaryotes was $94.9 \% ; 40 \%$ of the bacterial clones and $45 \%$ of the chemotrophic ones showed a similarity of less than $95 \%$ to known SSU rRNA gene sequences. The highest similarity to cultured strains has been found in clones Dolo-40 and Dolo-28 with similarities of $99.4 \%$ and $98.8 \%$, respectively, they are related to Brevundimonas variabilis, an $\alpha$-proteobacterium. The lowest degree of similarity as compared with known $16 \mathrm{~S}$ rRNA genes showed the clones Dolo-07, Dolo-17, and Dolo-29 with similarities of around $84 \%$.

The observation of an in vivo absorption peak at about $720 \mathrm{~nm}$ in the pigments of the endolithic populations [42] suggests the presence of organisms from the branch of green 
nonsulfur phototrophs. These organisms were originally thought to live only in extreme environments such as hot springs $[9,38,39,70,71]$, but some time ago, they were also found in temperate and even cold environments, such as wastewater treatment systems [4, 8, 80], the deep ocean [33], endolithic systems [17, 67, 89], as well as subsurface soil (paleosol) at a depth of $188 \mathrm{~m}$ [14]. Our sequence data confirm the presence of several green nonsulfur strains in the dolomite rock of the Piora Valley.

As in Antarctic endolithic communities [17, 83], except for Cyanobacteria and Actinobacteria, many phylotypes appeared in low numbers or even just as one, suggesting that the diversity must be substantially larger than presented by the clone libraries. This contrasts with some of the rarefaction curves obtained (Fig. 1), which level off rapidly. We assume that this rapid flattening of some curves in Fig. 1 is due to technical limitations such as biased DNA extractions and/or insufficiently fitting amplification primers for the communities in question.

While Smith et al. [83], de la Torre et al. [17], and Sigler et al. [82] did not describe any Archaea in endolithic communities, Crenarchaeota phylotypes were found in the Rocky Mountains and in deep-sea basalt [55, 89]. In the phylogenetic tree with the archaeal branch (Fig. 4) the three sampling sites show a different distribution. Together with sequences from Australian marine stromatolites [67] and other uncultured Crenarchaea, samples from marine basalt \{clone BECC1196b-18 (EF067896) as representative\} group closely around Cenarchaeum symbiosum. On the other hand, the archaeal clones from the Rocky Mountains partially group around our clones ud14 and DOS_02 or form a slightly different group clustered around the clone "ARC_1SAF3-56" (DQ782359) from a clean assembly room for NASA spacecraft [61] but are still closer to ud14 than to the basalt group. Interestingly, many other locations all over the world harbor Crenarchaea similar to the ones in the Piora dolomite, such as snow from Jungfraujoch in the Swiss Alps (AJ867733), for example, or soil from a rarely flooded plain by the river Waal in The Netherlands (AJ608203), or slit from a hot spring near Naples (Italy; AY650015), or the ODP 892 b borehole in the Pacific (AY367315), or soil in an agricultural research station in Madison (USA; U62812), or soil in the former Lake Texcoco close to Mexico City (EF690622), or in excaved material from a borehole, $200 \mathrm{~m}$ deep, of an oil drilling project in Japan (AB126373), or in the sediment of the Lonar Crater Lake in India (DQ302464).

On the whole, the archaeal sequences from the arid endolithic sites [present study and 89] are more related to each other than to endolithic organisms from aquatic sites [55]. A similar clustering has been observed in the group of the Cyanobacteria. The phylogenetic cluster formation of clones in similar habitats is more common than that of clones which live in different environments and are geographically further apart from each other. This indicates that both, geographical distances of the habitats and site-specific environmental factors have an influence on the biogeography of the organisms.

Among the heterotrophs, phagotrophic protists, mainly ciliates and flagellates, play an important role in the nutrient cycle as consumers of bacteria in aquatic environments. It has recently been discovered that Amoeba feed on cyanobacteria [97]. It is, thus, of special interest to find such consumers also in dry endolithic environments, where cyanobacteria form a large part of the biomass.

\section{Conclusion}

The results presented in this paper demonstrate that the bacterial diversity in endolithic habitats, especially of chemotrophic, nonpigmented organisms, is considerable but has been hidden and, therefore, underestimated previously. As most of the sequences have only been found once or in low numbers, a much greater diversity than the one described here may be expected. The finding of some ribosomal sequences of the crenarchaeal branch demands for a more detailed study of the Archaea.

Acknowledgements We are grateful to Steven M. Holland for providing his program Analytic Rarefaction as well as to John Marti for some revisions of the manuscript. And last but not least, we would like to thank the reviewers for their helpful comments and corrections.

\section{References}

1. Altschul SF, Madden TL, Schäffer AA, Zhang J, Zhang Z, Miller W, Lipman DJ (1997) Gapped BLAST and PSI-BLAST: a new generation of protein database search programs. Nucleic Acids Res 25:3389-3402

2. Ascaso C, Wierzchos J (2002) New approaches to the study of Antarctic lithobiontic microorganisms and their inorganic traces, and their application in the detection of life in Martian rocks. Int Microbiol 5:215-222

3. Barton HA, Taylor MR, Pace NR (2004) Molecular phylogenetic analysis of a bacterial community in an oligotrophic cave environment. Geomicrobiol J 21:11-20

4. Beer M, Seviour EM, Kong Y, Cunningham M, Blackall LL, Seviour RJ (2002) Phylogeny of the filamentous bacterium Eikelboom Type 1851, and design and application of a 16S rRNA targeted oligonucleotide probe for its fluorescence in situ identification in activated sludge. FEMS Microbiol Lett 207:179-183

5. Bell RA, Athey PV, Sommerfeld MR (1986) Cryptoendolithic algal communities of the Colorado Plateau. J Phycol 22:429-435

6. Bell RA, Athey PV, Sommerfeld MR (1988) Distribution of endolithic algae on the Colorado Plateau of Northern Arizona. Southwest Nat 33:315-322

7. Bell RA (1993) Cryptoendolithic algae of hot semiarid lands and deserts. J Phycol 29:133-139

8. Björnsson L, Hugenholtz P, Tyson GW, Blackall LL (2002) Filamentous Chloroflexi (green non-sulfur bacteria) are abundant 
in wastewater treatment processes with biological nutrient removal. Microbiol 148:2309-2318

9. Boomer SM, Lodge DP, Dutton BE, Pierson B (2002) Molecular characterization of novel red green nonsulfur bacteria from five distinct hot spring communities in Yellowstone National Park. Appl Environ Microbiol 68:346-355

10. Buckley DH, Graber JR, Schmidt TM (1998) Phylogenetic analysis of nonthermophilic members of the kingdom Crenarchaeota and their diversity and abundance in soils. Appl Environ Microbiol 64:4333-4339

11. Burggraf S, Stetter KO, Rouviere P, Woese CR (1991) Methanopyrus kandleri: an archaeal methanogen unrelated to all other known methanogens. Syst Appl Microbiol 14:346-351

12. Cappitelli F, Principi P, Pedrazzani R, Toniolo L, Sorlini C (2007) Bacterial and fungal deterioration of the Milan Cathedral marble treated with protective synthetic resins. Science Total Environ 385:172-181

13. Cavender JA (1978) Taxonomy with confidence. Math Biosci 40:271-280

14. Chandler DP, Brockman FJ, Bailey TJ, Fredrickson JK (1998) Phylogenetic diversity of Archaea and Bacteria in a deep subsurface paleosol. Microb Ecol 36:37-50

15. Cockell CS, Lee P, Osinski G, Horneck G, Broady P (2002) Impact-induced microbial endolithic habitats. Meteoritics Planetary Science 37:1287-1298

16. Cockell ChS, Lee P, Broady P, Lim DSS, Osinski GR, Parnell J, Koeberl Ch, Pesonen L, Salminen J (2005) Effects of asteroid and comet impacts on habitats for lithophytic organisms - A synthesis. Meteoritics Planetary Science 40:1901-1914

17. de la Torre JR, Goebel BM, Friedmann EI, Pace NR (2003) Microbial diversity of cryptoendolithic communities from the McMurdo Dry Valleys, Antarctica. Appl Environ Microbiol 69:3858-3867

18. de los Rios A, Grube M, Sancho LG, Ascaso C (2007) Ultrastructural and genetic characteristics of endolithic cyanobacterial biofilms colonizing Antarctic granite rocks. FEMS Microbiol Ecol 59:386-395

19. Diels L (1914) Die Algen-Vegetation der Südtiroler Dolomitriffe. Ber Dtsch Bot Ges 32:502-526

20. Edwards U, Rogall T, Blöcker H, Emde M, Böttger EC (1989) Isolation and direct complete nucleotide determination of entire genes. Characterization of a gene coding for $16 \mathrm{~S}$ ribosomal RNA. Nucleic Acids Res 17:7843-7853

21. Felsenstein J (1985) Confidence limits on phylogenies: An approach using the bootstrap. Evolution 39:783-791

22. Ferris FG, Lowson EA (1997) Ultrastructure and geochemistry of endolithic microorganisms in limestone of the Niagara escarpment. Can J Microbiol 43:211-219

23. Friedmann EI (1971) Light and scanning electron microscopy of the endolithic desert algal habitat. Phycologia 10:411-428

24. Friedmann EI, Ocampo R (1976) Endolithic blue-green algae in the Dry Valleys: primary producers in the Antarctic desert ecosystem. Science 193:1247-1249

25. Friedmann EI (1980) Endolithic microbial life in hot and cold deserts. Orig Life 10:223-235

26. Friedmann EI (1982) Endolithic microorganisms in the Antarctic cold desert. Science 215:1045-1053

27. Friedmann EI, Kappen L, Meyer MA, Nienow JA (1993) Longterm productivity in the cryptoendolithic microbial community of the Ross Desert, Antarctica. Microb Ecol 25:51-69

28. Garbary DJ, Van Thielen N, Miller A (1996) Endolithic algae from gypsum in Nova Scotia. J Phycol 32(Suppl):17

29. Garcia-Pichel F, Lopez-Cortes A, Nübel U (2001) Phylogenetic and morphological diversity of cyanobacteria in soil desert crusts from the Colorado Plateau. Appl Environ Microbiol 67:1902-1910

30. Garty J (2000) Lithobionts in the eastern mediterranian. In: Seckbach J (ed) Journey to diverse microbial worlds, adaptation to exotic environments. Kluwer Academic, Norwell, pp 257-277
31. Gerrath JF, Gerrath JA, Larson DW (1995) A preliminary account of endolithic algae of limestone cliffs of the Niagara Escarpment. Can J Bot 73:788-793

32. Gerrath JF, Gerrath JA, Matthes U, Larson DW (2000) Endolithic algae and cyanobacteria from cliffs of the Niagara Escarpment, Ontario, Canada. Can J Bot 78:807-815

33. Giovannoni SJ, Rappé MS, Vergin KL, Adair NL (1996) 16S rRNA genes reveal stratified open ocean bacterioplankton populations related to the Green Non-Sulfur bacteria. Proc Natl Acad Sci USA 93:7979-7984

34. Golubic S, Friedmann EI, Schneider J (1981) The lithobiotic ecological niche, with special reference to microorganisms. J Sediment Res 51:475-478

35. Gorbushina AA (2007) Life on the rocks. Environ Microbiol 9:1613-1631

36. Grossmann AR, Schaefer MR, Chiang GG, Collier JL (1994) The responses of cyanobacteria to environmental conditions: light and nutrients. In: Briant DA (ed) The molecular biology of cyanobacteria. Kluwer Academic, Dordrecht, pp 641-675

37. Hallam SJ, Konstantinidis KT, Putnam N, Schleper C, Watanabe Y, Sugahara J, Preston C, de la Torre J, Richardson PM, DeLong EF (2006) Genomic analysis of the uncultivated marine crenarchaeote Cenarchaeum symbiosum. Proc Natl Acad Sci U S A 103:18296-18301

38. Hanada S, Hiraishi A, Shimada K, Matsuura K (1995) Chloroflexus aggregans sp. nov., a filamentous phototrophic bacterium which forms dense cell aggregates by active gliding movement. Int J Syst Bacteriol 45:676-681

39. Hanada S, Takaichi S, Matsuura K, Nakamura K (2002) Roseiflexus castenholzii gen. nov., sp. nov., a thermophilic filamentous, photosynthetic bacterium that lacks chlorosomes. Int J Syst Evol Bacteriol 52:187-193

40. Hofmann BA, Farmer JD (2000) Filamentous fabrics in lowtemperature mineral assemblages: are they fossil biomarkers? Implications for the search for a subsurface fossil record on the early Earth and Mars. Planet Space Sci 48:1077-1086

41. Horath Th, Neu ThR, Bachofen R (2004) Endolithic populations in dolomite rock. 63rd Annual Assembly of the Swiss Society of Microbiology, Lugano

42. Horath Th, Neu ThR, Bachofen R (2006) An endolithic microbial community in dolomite rock in Central Switzerland: characterization by reflection spectroscopy, pigment analyses, scanning electron microscopy, and laser scanning microscopy. Microb Ecol 51:353-364

43. Horowitz NH, Cameron RE, Hubbard JS (1972) Microbiology of the Dry Valleys of Antarctica. Science 176:242-245

44. Hughes KA, Lawley B (2003) A novel Antarctic microbial endolithic community within gypsum crusts. Environ Microbiol 5:555-565

45. Jaag O (1945) Untersuchungen über die Vegetation und Biologie der Algen des nackten Gesteins in den Alpen, im Jura und im schweizerischen Mittelland. Beitr Kryptogamenflora Schweiz 9:1-560

46. Judson O (2004) Some Things Are Better Left on Mars. The New York Times. April 19, 2004 [http://www.nytimes.com/2004/ 04/19/opinion/19JUDS.html?ex =1083442884\&ei=1\&en=b0629 b4e2e7f63ea]

47. Komarek J (2003) Coccoid and colonial cyanobacteria. In: Wehr JD, Sheath RG, Thorp JH (eds) Freshwater algae of North America. Elsevier Science, Amsterdam, pp 59-116

48. Kuhlmann KR, Fusco WG, La Duc MT, Allenbach LB, Ball CL, Kuhlman GM, Anderson RC, Erickson IK, Stuecker T, Benardini J, Strap JL, Crawford RL (2006) Diversity of microorganisms within rock varnish in the Whipple Mountains, California. Appl Environ Microbiol 72:1708-1715

49. Lane DJ, Pace B, Olsen GJ, Stahl DA, Sogin ML, Pace NR (1985) Rapid determination of $16 \mathrm{~S}$ ribosomal RNA sequences for phylogenetic analyses. Proc Natl Acad Sci 82:6955-6959 
50. Lane DJ (1991) 16S/23S rRNA sequencing. In: Stackebrandt E, Goodfellow M (eds) Nucleic acid techniques in bacterial systematics. Wiley, New York, pp 115-175

51. Ley RE, Harris JK, Wilcox J, Spear JR, Miller SR, Bebout BM, Maresca JA, Bryant DA, Sogin ML, Pace NR (2006) Unexpected diversity and complexity of the Guerrero Negro hypersaline microbial mat. Appl Environ Microbiol 72:3685-3695

52. Ludwig W, Schleifer KH (1994) Bacterial phylogeny based on $16 \mathrm{~S}$ and 23S rRNA sequence-analysis. FEMS Microbiol Revs 15:155-173

53. Ludwig W, Klenk HP (2001) Overview: A phylogenetic backbone and taxonomic framework for prokaryotic systamatics. In: Boone DR, Castenholz RW (eds) Bergey's manual of systematic bacteriology. Springer, Berlin, pp 49-65

54. Ludwig W, Strunk O, Westram R, Richter L, Meier H, Yadhukumar XY, Buchner A, Lai T, Steppi S, Jobb G, Förster W, Brettske I, Gerber S, Ginhart AW, Gross O, Grumann S, Hermann S, Jost R, König A, Liss T, Lüßmann R, May M, Nonhoff B, Reichel B, Strehlow R, Stamatakis A, Stuckmann N, Vilbig A, Lenke M, Ludwig T, Bode A, Schleifer KH (2004) ARB: a software environment for sequence data. Nucleic Acids Res 32:1363-1371

55. Mason OU, Stingl U, Wilhelm LJ, Moeseneder MM, Di MeoSavoie CA, Fisk MR, Giovannoni SJ (2007) The phylogeny of endolithic microbes associated with marine basalts. Environ Microbiol 9:2539-2550

56. Matthes-Sears U, Gerrath JA, Larson DW (1997) Abundance, biomass, and productivity of endolithic and epilithic lower plants on the temperate-zone cliffs of the Niagara Escarpment, Canada. Int J Plant Sci 158:451-460

57. Matthes-Sears U, Gerrath JA, Gerrath JF, Larson DW (1999) Community structure of epilithic and endolithic algae and cyanobacteria on cliffs of the Niagara Escarpment. J Veg Sci 10:587-598

58. McKay CP, Friedmann EI (1985) The cryptoendolithic microbial environment in the Antarctic cold desert: temperature variations in nature. Polar Biol 4:19-25

59. McKay CP (1993) Relevance of antarctic microbial ecosystems to exobiology. In: Friedmann EI (ed) Antarctic microbiology. WileyLiss, New York, pp 593-601

60. Messing J (1983) New M13 Vectors for Cloning. Method Enzymol 101:20-78

61. Moissl C, Bruckner JC, Venkateswaran K (2008) Archaeal diversity analysis of spacecraft assembly clean rooms. ISME J 2:115-119

62. McNamara CJ, Perry TD, Bearce KA, Hernandez-Duque G, Mitchell R (2006) Epilithic and endolithic bacterial communities in limestone from a Maya archaeological site. Microb Ecol 51:51-64

63. Nealson K, Berelson W (2003) Layered microbial communities and the search for life in the universe. Geomicrobiol J 20:451-462

64. Nienow JA, Friedmann EI (1993) Terrestrial lithophytic (rock) communities. In: Friedmann EI (ed) Antarctic microbiology. Wiley-Liss, New York, pp 343-412

65. Norris TB, Castenholz RW (2006) Endolithic photosynthetic communities within ancient and recent travertine deposits in Yellowstone National Park. FEMS Microbiol Ecol 57:470-483

66. Nübel U, Garcia-Pichel F, Muyzer G (1997) PCR primers to amplify 16S rRNA genes from cyanobacteria. Appl Environ Microbiol 63:3327-3332

67. Papineau D, Walker JJ, Mojzsis SJ, Pace NR (2005) Composition and structure of microbial communities from stromatolites of Hamelin Pool in Shark Bay, Western Australia. Appl Environ Microbiol 71:4822-4832

68. Pentecost A (1992) Growth and distribution of endolithic algae in some North Yorkshire streams (UK). Brit Phycol J 27:145-151

69. Pentecost A, Bayari S, Yesertener C (1997) Phototrophic microorganisms of the Pamukkale travertine, Turkey: their distribution and influence on travertine deposition. Geomicrobiol J 14:269-283
70. Pierson BK, Castenholz RW (1974a) A phototrophic gliding filamentous bacterium of hot springs. Chloroflexus aurantiacus gen. and sp. nov. Arch Microbiol 100:5-24

71. Pierson BK, Castenholz RW (1974b) Studies of pigments and growth in Chloroflexus aurantiacus, a phototrophic filamentous bacterium. Arch Microbiol 100:283-305

72. Rappé MS, Giovannoni SJ (2003) The uncultured microbial majority. Annu Rev Microbiol 57:369-394

73. Rothschild LJ, Mancinelli RL (2001) Life in extreme environments. Nature 409:1092-1101

74. Russell NC, Edwards HGM, Wynn-Williams DD (1998) FTRaman spectroscopic analysis of endolithic microbial communities from Beacon sandstone in Victoria Land, Antarctica. Antarct Sci 10:63-74

75. Sambrook J, Fritsch EF, Maniatis Th (1989) Molecular cloning - a laboratory manual, 2nd edn. Cold Spring Harbour Laboratory Press, Cold Spring Harbour

76. Schloss PD, Handelsman J (2004) Status of the microbial census. Microbiol Mol Biol Rev 68:686-691

77. Schnider-Keel U, Lejbølle KB, Baehler E, Haas D, Keel C (2001) The Sigma Factor AlgU (AlgT) controls exopolysaccharide production and tolerance towards desiccation and osmotic stress in the biocontrol agent Pseudomonas fluorescens CHA0. Appl Environ Microbiol 67:5683-5693

78. Schönhuber W, Zarda B, Eix S, Rippka R, Herdman M, Ludwig W, Amann RI (1999) In situ identification of cyanobacteria with horseradish peroxidase- labeled, rRNA-targeted oligonucleotide probes. Appl Environ Microbiol 65:1259-1267

79. Schröter C (1908) Das Pflanzenleben der Alpen. Raustein, Zürich

80. Sekiguchi Y, Takahashi H, Kamagata Y, Ohashi A, Harada H (2001) In situ detection, isolation and physiological properties of a thin filamentous microorganism abundant in methanogenic granular sludges: a novel isolate affiliated with a clone cluster, the green non-sulfur bacteria, subdivision I. Appl Environ Microbiol 67:5740-5749

81. Sigler WV, Horath Th, Neu Th, Bachofen R (2002) Endolithic microbial populations in dolomite rock. Abstract 207, Int. Symp. Subsurface Microbiol. (ISSM-02) Copenhagen 2002.

82. Sigler WV, Bachofen R, Zeyer J (2003) Molecular characterization of endolithic cyantobacteria inhabiting exposed dolomite in central Switzerland. Environ Microbiol 5:618-627

83. Smith MC, Bowman JP, Scott FJ, Line MA (2000) Sublithic bacteria associated with Antarctic quartz stones. Antarct Sci 12:177-184

84. Stackebrandt E, Ebers J (2006) Taxonomic parameters revisited: tarnished gold standards. Microbiol Today 33:152-155

85. Stahl DA, Amann RI (1991) Development and application of nucleic acid probes. In: Stackebrandt E, Goodfellow M (eds) Nucleic acid techniques in bacterial systematics. Wiley, New York, pp 205-248

86. Taton A, Grubisic S, Brambilla E, De Wit R, Wilmotte A (2003) Cyanobacterial diversity in natural and artificial microbial mats of Lake Fryxell (McMurdo Dry Valleys, Antarctica): a morphological and molecular approach. Appl Environ Microbiol 69:5157-5169

87. Van Thielen N, Garbary DJ (2000) Life in the rocks - endolithic algae. In: Seckbach J (ed) Journey to diverse microbial worlds, adaptation to exotic environments. Kluwer, Dordrecht, pp 245-253

88. Walker JJ, Spear JR, Pace NR (2005) Geobiology of a microbial endolithic community in the Yellowstone geothermal environment. Nature 434:1011-1014

89. Walker JJ, Pace NR (2007a) Phylogenetic composition of Rocky Mountain endolithic microbial ecosystems. Appl Environ Microbiol 73:3497-3504

90. Walker JJ, Pace NR (2007b) Endolithic microbial ecosystems. Ann Rev Microbiol 61:331-347 
91. Warscheid Th, Braams J (2000) Biodeterioration of stone: a review. Int Biodeter Biodegr 46:343-368

92. Whitton BA, Potts M (1982) Marine littoral. In: Carr NG, Whitton BA (eds) The biology of cyanobacteria. Blackwell, Oxford, pp 515-542

93. Wierzchos J, Ascaso C (2001) Life, decay and fossilisation of endolithic microorganisms from the Ross Desert, Antarctica. Polar Biol 24:863-868

94. Wierzchos J, Ascaso C, Sancho LG, Green A (2003) Iron-rich diagenetic minerals are biomarkers of microbial activity in Antarctic rocks. Geomicrobiol J 20:15-24
95. Wynn-Williams DD, Edwards HGM (2000) Antarctic ecosystems as models for extraterrestrial surface habitats. Planet Space Sci 48:1065-1075

96. Wynn-Williams DD (2000) Cyanobacteria in deserts - life at the limit? In: Whitton BA, Potts M (eds) The ecology of cyanobacteria. Kluwer Academic Publishers, Dordrecht, pp 341-366

97. Xinyao L, Miao S, Yonghong L, Yin G, Zhongkai Z, Donghui W, Weizhong W, Chencai A (2006) Feeding characteristics of an amoeba (Lobosea: Naegleria) grazing upon cyanobacteria: food selection, ingestion and digestion progress. Microb Ecol 51:315-325 